\title{
Intravitreal pegaptanib sodium for refractory pseudophakic macular oedema
}

\begin{abstract}
Purpose Evaluate the efficacy of intravitreal pegaptanib sodium (Macugen ${ }^{\circledR}$ ) in refractory pseudophakic cystoid macular oedema (CME). Design and methods Prospective, nonrandomized, interventional case series. Four eyes of four patients with refractory pseudophakic CME to pars plana vitrectomy and intravitreal bevacizumab and triamcinolone, were treated with pegaptanib sodium, with a mean follow up of 4 months. Pre- and postinfection examinations included assessment of best-corrected visual acuity (BCVA) using the Early Treatment Diabetic Retinopathy Study chart (ETDRS), fluorescein angiography (FA), and optical coherence tomography (OCT).

Results Visual acuity increased in all patients after intravitreal pegaptanib sodium. OCT showed improvement of the retinal thickness in the macular area. Conclusion Intravitreal pegaptanib sodium (Macugen ${ }^{\circledR}$ ) is a promising treatment for pseudophakic cystoid macular oedema resistant to other medical treatment strategies. However, further study is needed to assess the treatment's long term efficacy and the need for retreatment.
\end{abstract}

Eye (2008) 22, 1180-1182; doi:10.1038/eye.2008.2; published online 18 April 2008

Keywords: pseudophakic; macular oedema; pegaptanib sodium; cystoid

\section{Introduction}

Postoperative cystoid macular oedema (CME) is a common complication after cataract surgery, with angiographic CME varying from 3 to $70 \%$ depending on the study, method of cataract
E Cervera1', M Diaz-Llopis ${ }^{1,2}$, P Udaondo ${ }^{1}$ and

S Garcia-Delpech ${ }^{1}$ surgery, operative complications as well as grading methods to assess CME. ${ }^{1}$ Fortunately, the advent of phacoemulsification techniques has dramatically reduced the occurrence of CME. $^{2}$

In mild cases, postoperative CME resolves spontaneously and requires no treatment, but other eyes may be resistant to common medical treatment strategies, including systemic or topical nonsteroidal anti-inflammatory agents or steroids, vitreolysis, ${ }^{3}$ and pars plana vitrectomy. ${ }^{4}$ More recently, intravitreal use of triamcinolone acetonide ${ }^{5-7}$ and bevacizumab (Avastin $\left.{ }^{\mathbb{R}}\right)^{8,9}$ has been offered as alternative treatment of persistent pseudophakic CME.

In this study, we prospectively studied the efficacy of intravitreal pegaptanib sodium (Macugen ${ }^{\circledR}$ ) by the use of optical coherence tomography (OCT) (Stratus OCT Model 3000, Humphrey Instruments, Carl Zeiss Inc., Dublin, CA, USA) and best-corrected visual acuity (BCVA) in four eyes of four patients with persistent refractory CME after cataract extraction, with a mean follow-up of 4 months.

\section{Materials and methods}

Four patients, aged 55-75 years, presented with pseudophakic refractory CME in four eyes lasting for 6-12 months following cataract surgery (Table 1). A minimum of two intravitreal injections of bevacizumab were administered in all patients (separated by a 5week period). Four injections were necessary for patient 2; although CME showed improvement after each injection, as measured by OCT, it reappeared after a short period of time. Intravitreal injection of triamcinolone was administered previously in patients 3 and 4 . Patient 1 underwent vitrectomy, because an important traction of the vitreous cortex on the macula was confirmed by OCT. Intravitreal 
Table 1 Characteristics of four patients with refractory CME treated with Macugen ${ }^{\mathbb{R}}$

\begin{tabular}{|c|c|c|c|c|c|c|c|}
\hline Patient & $\begin{array}{l}\text { Age } \\
\text { (years) }\end{array}$ & Type of surgery & $\begin{array}{l}\text { Duration } \\
\text { of CME }\end{array}$ & $\begin{array}{l}\text { Treatment before } \\
\text { Macugen injection }\end{array}$ & $\begin{array}{c}\text { Pre-injection } \\
\text { BCVA and } \\
\text { macular thickness }\end{array}$ & $\begin{array}{l}\text { Post-injection final } \\
\text { BCVA and macular } \\
\text { thickness at } 4 \text { month }\end{array}$ & $\begin{array}{l}\text { Second } \\
\text { injection }\end{array}$ \\
\hline \multirow[t]{2}{*}{1} & 75 & $\begin{array}{l}\text { Complicated cataract } \\
\text { extraction with } \\
\text { anterior IOL }\end{array}$ & 8 months & $\begin{array}{l}\text { Pars plana } \\
\text { vitrectomy }\end{array}$ & 1.0 & 0.8 & No \\
\hline & & & & $\begin{array}{l}\text { Two intravitreal } \\
\text { bevacizumab }\end{array}$ & $360 \mu$ & $260 \mu$ & \\
\hline \multirow[t]{2}{*}{2} & 78 & $\begin{array}{l}\text { Complicated cataract. } \\
\text { Secondary IOL } \\
\text { implantation }\end{array}$ & 9 months & $\begin{array}{l}\text { Four intravitreal } \\
\text { bevacizumab }\end{array}$ & 0.6 & 0.26 & Yes \\
\hline & & & & & $416 \mu$ & $230 \mu$ & \\
\hline \multirow[t]{2}{*}{3} & 56 & $\begin{array}{l}\text { Not complicated } \\
\text { cataract }\end{array}$ & 6 months & $\begin{array}{l}\text { One intravitreal } \\
\text { triamcinolone }\end{array}$ & 0.5 & 0.1 & No \\
\hline & & & & $\begin{array}{l}\text { Two intravitreal } \\
\text { bevacizumab }\end{array}$ & 485 & $255 \mu$ & \\
\hline \multirow[t]{2}{*}{4} & 76 & $\begin{array}{l}\text { Not complicated } \\
\text { cataract }\end{array}$ & 12 months & $\begin{array}{l}\text { Two intravitreal } \\
\text { triamcinolone }\end{array}$ & 0.3 & 0.1 & No \\
\hline & & & & $\begin{array}{l}\text { Three intravitreal } \\
\text { bevacizumab }\end{array}$ & $389 \mu$ & $213 \mu$ & \\
\hline
\end{tabular}

BCVA = best-corrected visual acuity measured by logMar system; $\mathrm{CME}=$ cystoid macular oedema.

pegaptanib treatment was commenced at 6 weeks after the last bevacizumab injection. Only patient 2 needed a second injection of pegaptanib to get complete resolution of CME. Pre- and post-injection examinations included assessment of BCVA using the Early Treatment Diabetic Retinopathy Study chart (ETDRS), fluorescein angiography (FA), and OCT. CME was assessed by measuring the thickness of the $1 \mathrm{~mm}$ central macular area. Intravitreal injections of pegaptanib sodium (Macugen) were administered with full asepsis in the surgery room.

\section{Results}

In all four patients, macular thickness had decreased from a mean of $412 \pm 20$ to $239 \pm 20 \mu \mathrm{m} 1$ month after intravitreal pegaptanib sodium injection (Figure 1). By that time, BCVA had also improved (mean improvement 17 letters, equivalent to 3, 5 Snellen lines). Within 2-4 months, the oedema minimally recurred in one eye (patient 2), and the patient accepted a second intravitreal pegaptanib sodium injection, which again led to the regression of CME 1 month later.

\section{Discussion}

To the best of our knowledge, our four patients are the first reported cases of refractory pseudophakic macular oedema treated with pegaptanib sodium (Macugen). It is
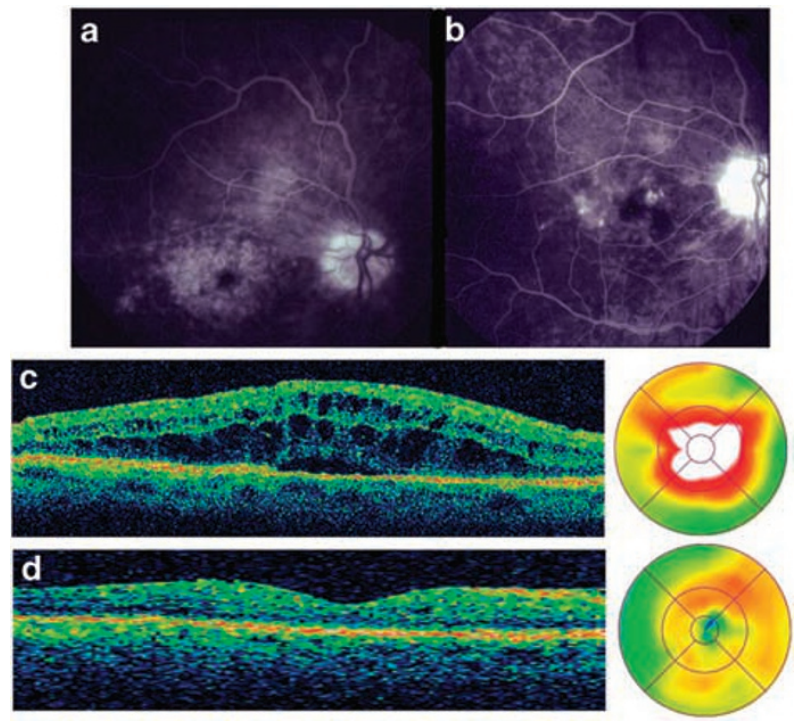

Figure 1 Fluorescein angiography and optical coherence tomography of patient 4. ( $a$ and $b$ ) Fluorescein angiogram before and after one pegaptanib injection. (c and d) Complete macular oedema resolution 15 days after the treatment measured by OCT in the same patient.

possible that resistance or tachyphylaxis to our new class of medications might develop after a sufficient time or number of treatments. VEGF is both a potent enhancer of vascular permeability and a key inducer of angiogenesis. Pegaptanib sodium, currently approved in the treatment 
of exudative age-related macular degeneration, binds to and inactivates VEGF165, which has been implicated as a potent permeability factor implicated in CME.

Pagaptanib has also demonstrated to be effective in retinal macular oedema due to vascular disorders such us diabetic retinopathy. ${ }^{10}$

Our four patients had severe vision loss, which was refractory to different treatments, included bevacizumab, but which responded to an intravitreal injection of pegaptanib sodium. The CME resolved clinically as well as by FA and OCT, with an important increase in visual acuity. There has been no recurrence of the CME and no complications from intravitreal pegaptanib sodium. The long-term outcome is currently unknown. CME recurrence is a possibility and may require additional therapy. VEGF-A has recently been recognised as an important neuroprotectant in central nervous system and retina, ${ }^{11}$ that is why we think that the chronic panVEGF inhibition can damage retina in vascular disorders and a specific inhibition of $\mathrm{VEGF}_{165}$ may be an effective alternative in the treatment of CME.

In conclusion, intravitreal pegaptanib sodium (Macugen) may be an excellent treatment modality for patients with $\mathrm{CME}$ unresponsive to other treatments.

\section{References}

1 Ray S, D'Amico DJ. Pseudophakic cystoid macular edema. Semin Ophthalmol 2002; 17(3): 167-180.

2 Nagpal M, Nagpal K, Nagpal PN. Postcataract cystoid macular edema. Ophthalmol Clin North Am 2001; 14: 651-659.
3 Steinert RF, Wasson PJ. Neodymium Yag Laser anterior vitreolysis for Irvine-Gass cystoid macular edema. J Cataract Refract Surg 1989; 15: 305-307.

4 Harbour JW, Smiddy WE, Rubsamen PE. Pars plana vitrectomy for pseudophakic macular edema. Am J Ophthalmol 1995; 120: 302-307.

5 Benhamou N, Massin P, Haouchine B, Audren F, Tadayoni $\mathrm{R}$, Gaudric A. Intravitreal triamcinolone for refractory pseudophakic macular edema. Am J Ophthalmol 2003; 135(2): 246-249.

6 Boscia F, Furino C, Damacco R. Intravitreal triamcinolone acetonide in refractory pseudophakic cystoid macular edema: functional and anatomic results. Eur J Ophthalmol 2005; 15: 89-95.

7 Koutsandrea C, Marilita M, Brouzas D, Loukianou E, Apostolopoulos M, Moschos M. Intraocular triamcinolone acetonide for pseudophakic cytoid macular edema. Retina 2007; 27(2): 159-164.

8 Mason JO, Albert MA, Vail R. Intravitreal bevacizumab (Avastin) for refractory pseudophakic cystoid macular edema. Retina 2006; 26(3): 356-357.

9 Diaz-Llopis M, Amselem L, Cervera E, Delpech S, Torralba C, Montero J. Intravitreal injection of Bevacizumab (Avastin ${ }^{\mathbb{R}}$ ) for pseudophakic cystoid macular edema resistant to steroids. Arch Soc Esp Oftalmol 2007; 82(7): 447-450.

10 Cunningham Jr ET, Adamis AP, Altaweel M, Aiello LP, Bressler NM, D'Amico DJ, et al., Macugen Diabetic Retinopathy Study Group. A phase II randomized doublemasked trial of pegaptanib, an anti-vascular endothelial growth factor aptamer, for diabetic macular edema. Ophthalmology 2005; 112(10): 1747-1757.

11 Nishijima K, Ng YS, Zhong L, Bradley J, Schubert W, Jo N et al. Vascular endothelial growth factor-a is a survival factor for retinal neurons and a critical neuroprotectant during the adaptive response to ischemic injury. Am J Pathol 2007; 171(1): 53-67. 